Simocephalus vetulus (O.F. Muller)

Material examined: Female, length $0.96 \mathrm{~mm}$, width $0.68 \mathrm{~mm}$, Jublee Park Lake.

\section{ON A COLLECTION OF CLADOCERA FROM DIMNA AND JUBLEE PARK LAKES, JAMSHEDPUR, JHARKHAND}

\author{
S.V.A. Chandrasekhar ${ }^{1}$ and Tapas Chatterjee ${ }^{2}$ \\ ${ }^{1}$ Zoological Survey of India, Freshwater Biological Station, 1-1- \\ 300/B, Ashoknagar, Hyderabad, Andhra Pradesh 500020, India \\ ${ }^{2}$ Department of Biology, Indian School of Learning, I.S.M. Annexe, \\ Dhanbad - 826004 , India
}

Gurney (1907), Brehm (1950), Nasar (1977), and, Rai and Sharma (1989) are some of the major contributions to the literature on cladocerans. Of the two perennial lakes (each ca.35ha) chosen for the study, Dimna Lake the oligotrophic one, is the main source of drinking water to Jamshedpur Town $\left(22^{\circ} 50^{\prime} \mathrm{N}\right.$ and $\left.86^{\circ} 10^{\prime} \mathrm{E}\right)$ and the eutrophic Jublee Park Lake is used for boating purpose. The Jublee Park Lake is eutrophicated completely and covered with micro and macrophytes. Out of the 19 species of Cladocerans reported earlier from Bihar State (Michael \& Sharma, 1988), nine species belonging to five genera and spread in three families, were recorded from the two lakes. This study has gained its significance due its first attempt to study the fauna of the two water bodies, now in Jharkhand State.

Plankton samples were collected by the second author by diving the plankton net (No. 25) with a 50ml capacity plastic container tied at its end on the sub-surface of the two lakes, in the month of February, 2002 (between 0800 and 0900hr). Samples were preserved with $4 \%$ formaldehyde solution. Cladoceran fauna was identified by the first author with the aid of standard keys (Michael \& Sharma, 1988; Battish, 1992).

\section{Systematic account}

Family: Daphniidae

\section{Ceriodaphnia cornuta Sars, 1885}

Material examined: Female, length $0.32 \mathrm{~mm}$, width $0.28 \mathrm{~mm}$, Dimna Lake and Jublee Park Lake.

Distribution: India: West Bengal, Bihar, Quilon, Rajasthan, Meghalaya

Ceriodaphnia reticulata (Jurine, 1820)

Material examined: Female, length $0.38 \mathrm{~mm}$, width $0.36 \mathrm{~mm}$, Jublee Park Lake.

Distribution: India: Rajasthan, Bihar.
Distribution: India: Punjab, Kashmir, Rajasthan, Bihar, West Bengal.

\section{Simocephalus exspinosus (Koch, 1841)}

Material examined: Female, length 0.9mm, width 0.6mm, Dimna Lake and Jublee Park Lake.

Distribution: India: Meghalaya, West Bengal.

Family: Moinidae

Moinodaphnia macleayi (King, 1853)

Material examined: Female, length $0.6 \mathrm{~mm}$, width $0.5 \mathrm{~mm}$, Dimna Lake

Distribution: India: Southern India, West Bengal.

Family: Chydoridae

Subfamily: Chydorinae

Chydorus sphaericus (O.F. Muller)

Material examined: Female, length $0.54 \mathrm{~mm}$, width $0.45 \mathrm{~mm}$, Dimna Lake

Distribution: India: West Bengal, Bihar, Kashmir, Ladakh, Nilgiri Hills and Meghalaya; elsewhere-cosmopolitan.

Chydorus parvus (Daday, 1898)

Material examined: Female; length $0.42 \mathrm{~mm}$, width $0.39 \mathrm{~mm}$, Dimna Lake

Distribution: India: West Bengal.

\section{Chydorus hermanni Brehm 1933}

Material examined: Female, length $0.4 \mathrm{~mm}$, width $0.37 \mathrm{~mm}$, Dimna Lake and Jublee Park Lake

Distribution: India: Southern India.

\section{Subfamily: Aloninae}

\section{Alona rectangula rectangula Sars, 1862}

Material examined: Female, length $0.48 \mathrm{~mm}$, width $0.36 \mathrm{~mm}$, Dimna Lake and Jublee Park Lake.

Distribution: India: Ladakh, Gujarat, Rajasthan, Kashmir, Meghalaya and West Bengal.

Of the nine species Ceriodaphnia cornuta, Simocephalus exspinosus, Chydorus hermanni and Alona rectangula rectangula were found from both the lakes. Moinodaphnia macleayi, Chydorus sphaericus and Chydorus parvus were observed only from Dimna Lake. According to Das (1989), the presence of Chydorus sphaericus and Simocephalus sp. indicate that the water body is oligotrophic and the presence of Ceriodaphnia sp. indicate eutrophication. On the basis of the study it can be said that Dimna Lake and Jublee Park Lake are 
oligotrophic and eutrophic respectively.

\section{Acknowledgements}

The authors are grateful to M/s Indian School of Mining, Dhanbad and Zoological Survey of India, Kolkata for extending facilities to carry out this work.

\section{References}

Battish, S.K. (1992). Freshwater Zooplankton of India. Oxford \& IBH Publishing Co. Pvt. Ltd., pp.130-172.

Brehm, V. (1950). Contribution to the Freshwater Fauna of India, Part I \& II. Records of the Indian Museum 48(1-3): 9-28.

Das, S.M. (1989). Hand Book of Limnology and Water Pollution with Practical Methodology South Asian Publishers Pvt. Ltd., New Delhi, pp.77-89.

Michael, G.R. and B.K. Sharma (1988). Fauna of India and Adjacent Countries, Indian Cladocera (Crustacea: Branchiopoda: Cladocera). Zoological Survey of India, 262pp.

Gurney, R. (1907). Further notes on Indian Freshwater Entomostraca. Records of the Indian Museum 1: 21-33.

Nasar, S.A.K. (1977). The Zooplankton (Bihar) II. Cladocera. Carcinological Society of Japan Researches on Crustacea No. 8: 3236.

Rai, D.N. and U.P. Sharma (1989). Zooplankton periodicity in weed infested wetlands of North Bihar. Journal of Freshwater Biology 1(2): 161-166.

\section{A PRELIMINARY LIST OF BUTTERFLIES OF RAMANATHAPURAM DISTRICT, TAMIL NADU}

\author{
N. Chitra ${ }^{1}$ and S. Mahendran ${ }^{2}$ \\ ${ }^{1}$ Research Associate, ${ }^{2}$ Professor and Head \\ Agricultural Research Station, Ramanathapuram, Tamil Nadu, \\ 623501, India.
}

\begin{abstract}
A survey was carried out as a part of an inventory of insect faunal composition in Ramanathapuram District in 2001, details of which will be published separately. Ramanathapuram District is situated on the southeastern coast of the Indian peninsula
\end{abstract}

between $11^{\circ}$ and $12^{\circ} \mathrm{N}$ and $77^{\circ} 28^{\prime}$ and $78^{0} 50^{\prime} \mathrm{E}$. The district is by and large hot and dry with low rainfall. The average maximum temperature and minimum temperature is $34.6^{\circ} \mathrm{C}$ and $22.11^{\circ} \mathrm{C}$ respectively. The average rainfall is $816 \mathrm{~mm}$ with a relative humidity between $60-70 \%$ in summer and $75-95 \%$ in winter. The butterflies were identified based on Gunathilagaraj et al. (1998). The butterflies recorded during the study period is listed in table 1.

We acknowledge the incessant encouragement given by Dr. K. Gunathilagaraj, Tamil Nadu Agricultural University, Coimbatore to initiate this study.

\section{Reference}

Gunathilagaraj, K., T.N.A. Perumal, K. Jayaram, and M. Ganeshkumar (1998). Some South Indian Butterflies. Nilgiri Wildlife and Environment Association, Udhagamandalam, 274pp.

\section{Table 1. Butterflies of Ramanathapuram District}

\begin{tabular}{ll}
\hline Scientific name & Common name \\
\hline Acraeidae & \\
Acraea violae (Fabricius) & Tawny Coster \\
Danaidae & \\
Danaus chrysippus chrysippus (Linnaeus) & Plain Tiger \\
Lycaenidae & \\
Azanus ubaldus Cramer & Bright Babul Blue \\
Nymphalidae & \\
Precis almana almana (Linnaeus) & Peacock Pansy \\
Precis peirta peirta (Linnaeus) & Yellow Pansy \\
Precis lemonias lemonias (Linnaeus) & Lemon Pansy \\
Paplionidae & \\
Graphium agamemnon menides Felder \& Felder & Tailed Jay \\
Papilio demoleus Linnaeus & Lime Butterfly \\
Papilio polytes stichius (Hubner) & Common Mormon \\
Pieridae & \\
Catopsilia crocale (Cramer) \\
Catopsilia pyranthe (Linnaeus) \\
Delias eucharis (Drury)
\end{tabular}

